\title{
Automatic segmentation of clinical OCT images for the determination of epithelial thickness changes in laryngeal lesions
}

\author{
Henning Wisweh, Laura Martinez Mateu, Marcel Kraft, Alexander Krüger, Holger Lubatschowski \\ From 2nd Scientific Meeting of the Head and Neck Optical Diagnostics Society \\ San Francisco, CA, USA. 23-24 January 2010
}

Automated classification of laryngeal lesions using optical coherence tomography data can be helpful in making a faster and safer diagnosis. A change in the epithelial layer thickness seems to be an effective indicator for laryngeal cancer and its precursors.

Lesions with different grades of malignancy were scanned with a time domain OCT system during microlaryngoscopy. Every diagnosis was confirmed by performing a biopsy. Each OCT image was separately segmented, manually by an expert and automatically by a segmentation algorithm. Values for the maximal and average epithelial thickness as well as the standard deviations were compared for both segmentations. The results show a thickening of the epithelium from normal over dysplastic to cancerous tissue. The values for the automatic segmentation are in good agreement with expert segmentation.

In conclusion, automatic segmentation can be used for epithelial thickness measurements as a promising indicator for laryngeal cancer. It would also be possible to extract other characteristics like standard deviation or signal attenuation within the segments. Thus, we laid the foundation for computer-aided diagnosis of laryngeal lesions.

Published: 29 October 2010

doi:10.1186/1758-3284-2-S1-09

Cite this article as: Wisweh et al: Automatic segmentation of clinical OCT images for the determination of epithelial thickness changes in laryngeal lesions. Head \& Neck Oncology 20102 (Suppl 1):O9.

Department of ORL, Tellstr, Aarau, Switzerland
Submit your next manuscript to BioMed Central and take full advantage of:

- Convenient online submission

- Thorough peer review

- No space constraints or color figure charges

- Immediate publication on acceptance

- Inclusion in PubMed, CAS, Scopus and Google Scholar

- Research which is freely available for redistribution

Submit your manuscript at www.biomedcentral.com/submit
C Biomed Central 